sciendo

\title{
Job Polarization in Europe: \\ EVIDENCE FROM CENTRAL AND EASTERN EUROPEAN COUNTRIES
}

\author{
Dennis Nchor ${ }^{1}$, Petr Rozmahel $^{2}$
}

\begin{abstract}
Job polarization simply refers to the decline or disappearance of employment in middle skill occupations. Recent literature focuses on this phenomenon as a source of rising income inequality in countries. The hypothesis is that growth in employment over the last decades has favoured jobs at the low and high skill occupations with declines in employment shares in the middle of the distribution. First, this paper seeks to investigate whether labour polarization occurs in Central and Eastern European countries. Secondly, the paper assesses the role of technology on employment in the Central and Eastern European countries. Using employment shares and a cointegrated panel autoregressive distributed lag model, the paper presents comprehensive results on labour polarization and the impact of technology on employment in the labour markets of the Central and Eastern European countries. The results show positive impact of technology on high skill employment while negative on low and middle skill employment in the long-run. The study finds that though middle skill employment shares declined, there is no clear case of a U-shape employment distribution to indicate labour polarization.
\end{abstract}

\section{Keywords}

Employment, Skill, Polarization, Routine, Labour

\section{Introduction}

The structure of employment distribution in labour markets of countries is changing and it is imperative to understand those changes and their implications. In the 1990s there was a shift in employment towards educated workers and that was explained using the idea of Skill-Biased Technological Change (SBTC) hypothesis (see Autor and Katz, 1999). According to this hypothesis, labour demand develops in line with rising skills and knowledge. In other words, the theory suggests a positive relationship between the demand for labour and education skills. This hypothesis however leads to a simple prediction of a shift in employment from low skilled occupations towards high skilled occupations.

\footnotetext{
${ }^{1}$ Mendel University in Brno, Zemědělská 1, 61300 Brno, Czech Republic. E-mail: dennis.nchor@mendelu.cz.

${ }^{2}$ Mendel University in Brno, Zemědělská 1, 61300 Brno, Czech Republic. E-mail: petr.rozmahel@mendelu.cz.
} 
Recent observations in the labour markets of some advance countries have however shown growth in employment in both high skill and low skill occupations (see Goos and Manning 2007) with a disappearance of employment in middle skill occupations. This phenomenon is widely referred to as labour polarization which led to the introduction of a new theory called the Routine Biased Technological Change (RBTC) hypothesis. RBTC suggests that recent technological change is biased towards replacing labour in routine tasks. It predicts a decrease in the demand for middle skill workers relative to high skill and low skill because most tasks in the middle of the distribution are routine in nature.

Despite the rising popularity of the routine biased logic in explaining the role of robotization and automation in the changing labour market, evidence on labour polarization in Europe remains ambiguous in empirical literature with some studies finding no evidence of labour polarization (Oesch and Rodriguez Menez, 2011) and others concluding with evidence of polarization (Goos et al. 2014). One associated question that arose from studies on the labour polarization phenomenon is whether the role of technology is a strong factor in producing such seemingly U-shape structural change in employment in the labour markets. Studies that explored the impact of technology on the changing employment structure include Rotman (2013), Deane (2013), Brynjolfsson and McAfee (2011). The findings of these studies suggest a significant role of technology in the changing employment distribution. Other authors disagree with the negative perception assigned the influence of technology on overall employment (Miller and Atkinson 2013; and Bessen 2013) concluding that technology leads to growth in output which creates more jobs.

This study examines the case of Central and Eastern European countries (CEE). Specifically, Bulgaria, Czech Republic, Hungary, Poland, Romania, and Slovakia. The relevance of this topic is due to the huge socio-economic and political implications of labour market polarization and technologically induced unemployment in the CEE countries. Firstly, the existence of labour polarization leads to widening income inequality as active labour is unable to contribute productively. Secondly, workers see gainful employment as linked to self-worth (Deane 2013) thus, labour market polarization and technologically induced unemployment contribute to social stigmatization and other problems (Baker and Hassett 2012). Thirdly high rate of unemployment as a result of labour market polarization and technological displacements could lead to collective disruptions in the form of mass protests from dissatisfied labour who feel left behind in permanent poverty and despair.

There is lack of extensive literature dealing with labour polarization and employment structural changes in the CEE countries and taking into consideration the rather different institutional background of the labour market in this post-communist bloc, the study aims to contribute in respect of labour polarization in the six Central and Eastern European countries. First, the study seeks to investigate whether labour polarization occurs in the six countries. Secondly, it assesses the role of technology in the changing employment structure in their labour markets. The study uses comparative descriptive statistics to analyse employment structural changes. In particular, the employment shares and employment trend analysis are used to highlight the changes within and between skill groups. This methodology has been used in related literature and, crucially, in the works of Goos and Manning (2007). Secondly, the paper uses a panel cointegrated autoregressive 
distributed lag model to assess the impact of technology on the changing employment structure.

The structure of the paper is as follows: the first section introduces the objective and explains motivation for researching the case of labour polarization in Central and Eastern Europe. The second part reviews the literature on the topic. The third part describes and explains the methods and data. The results of the comparative analysis of labour polarization and ARDL model are presented and discussed in the fourth section. The fifth section concludes the findings.

\section{Literature Review}

Declining middle-class jobs have been a topical issue in US, Europe and some other countries in the world for the past decades. This decline is viewed from two points of view. First, the number of well-paid middle skill jobs has decreased substantially in recent years. Second, the earnings for workers around the median of the wage distribution dropped over the same period, leaving them with hardly any real wage gains. At the opposite end of the skill distribution, employment and earnings are increasing in both low and high skill jobs. This is what the data from the U.S. and some European countries shows. This phenomenon is termed as job polarization. Such development of employment structure and earnings is rather incompatible with skill and knowledge biased labour market theories.

Recent literature examines extensively the impact of technological transition upon labour markets. Skill biased technological change hypothesis (SBTC) expects labour upgrading due to technological progress. Labour demand develops in line with rising skills and knowledge according to that approach. In other words, this theory (see Goldin and Katz, 2008; Acemoglu and Autor, 2011) suggests a positive correlation between the demand for labour, education and skills. Higher requirements for knowledge and skills due to technological transformation are supposed to induce rising demand for labour in favour of the better educated and skilled. Still, the SBTC hypothesis cannot emphatically explain the recent phenomenon of job polarization as documented by Autor, Katz and Kearney (2006) and Autor and Dorn (2013) for the US and Goos and Manning (2007) for the UK. The above-mentioned literature including e.g. Autor, Levy and Murnane (2003), Goos, Manning and Solomons (2014) suggests the extent of task routinization to explain the polarizing labour markets.

Regarding evidence on polarizing labour markets in some countries, literature seeks to explain theoretically the role of technology and other factors in that phenomenon. Routine biased technological change hypothesis (RBTC) suggests that recent technological change is biased towards replacing labour in routine tasks and that there is task offshoring. They conclude that both forces decrease the demand for middle skill workers relative to high skill and low skill occupations. Computers, algorithms and robots replace workers in jobs with high intensity of routine tasks, whereas the creative and abstract thinking intensive occupations as well as elementary manual occupations are rather complemented by technologies according to this approach. 
The situation in Europe does not seem so clear. There are studies concluding that labour polarization occurs across Western Europe as observed by Spitz-Oener (2006) and PertoldGebicka (2014). Germany, Sweden, Spain and the U.K. are considered as polarized countries by Goos et al. (2014), Bernardi and Garrido (2008), Oesch and RodriquezMenes, (2011). The extent of polarization varies largely dependent on data, method, time span, measures of skill level activities and occupations. By contrast, some studies find job upgrading patterns showing rising demand for labour correlating with skills. Occupational upgrading is found by Tahlin (2007), Dustmann et al. (2009) and Hardy et al. (2018) in some European countries. Fernandez-Marciaz et al. (2012) did not find labour polarization in Spain contrary to Oesch and Rodriguez Menez (2011). Fernandez-Marciaz et al. (2012) also provide evidence on upgrading employment in Sweden, whereas the study by Adermon (2015) finds labour polarization there. Sarkar (2017) examining job-education mismatch assumes Spain and the UK as polarized countries whereas Germany and Sweden represent countries with upgrading patterns of employment change.

Regarding the unclear labour polarization evidence in literature one might ask whether the expected role of technology replacing the routine intensive jobs is so strong factor in producing such seemingly similar U-shape structural change in labour. Studies that explored the impact of technology on the changing employment structure include Rotman (2013), Deane (2013), Brynjolfsson and McAfee (2011). The findings of these studies suggest a significant role of technology in the changing employment distributions across the world. They also suggest that economic growth has become detached from employment growth. Other authors such as Miller and Atkinson (2013) and Bessen (2013) however disagree with the negative perception assigned the influence of technology on overall employment. They conclude that even though technology replaces jobs in some skill groups, growth in output leads to expansion which creates more jobs in other areas.

Technology has been addressed as the main driver of structural changes in the labour markets in literature. Seemingly diminishing middle skill jobs with high level of routine activities might have rather negative socio-economic impacts unless the middle skill workers have gone through re-training to get other middle skill or even high skill jobs. When middle skill workers move to low skill jobs or stay unemployed, it could have unwanted social impacts on individuals who are members of the middle societal class being considered as the median voters. Losing that middle-class life might lead to dissatisfied voters seeking for change in terms of the political environment. These extreme groups usually become influential politically in some countries (See Hainmueller et al, 2011). It leads to political or social unrest.

The socio-economic, political implications and the role of robots have been probably the reasons why labour polarization issue has become a popular topic in recent literature. Still, the literature is rather heterogenous in terms of methodology and main findings. In spite of the fact that studies vary in indicating the common changing patterns of employment in the European countries, in general a rise in demand for high skill workers exceeding the rest of the employment pool can be commonly found in contemporary literature. Apart from lack of consensus in the extent of polarized labour market in Western Europe, one finds limited literature focusing on Central and Eastern Europe (CEEC). 
Regarding different economic history of the CEE countries having the market economies based on the heritage of centrally planned systems and also with respect to historically strong socially oriented labour policies, one might expect different development of structural changes in employment in these countries. Lower flexibility, strong role of labour unions, different institutional background and relying on a comparative advantage of being low cost economy provide different conditions for the impact of technological transition upon labour market in the CEE countries. Contrary to common literature on labour polarization, our paper seeks to provide some evidence on whether it occurs in Central and Eastern European countries and to explain the role of technology in the changing employment structure.

\section{Methodology}

This study focuses on two research questions. The first is to investigate whether labour polarization occurs in Central and Eastern European countries. The second is to assess the impact of technology on employment structure in Central and Eastern European countries. The first research question is answered using changes in employment shares. The second is answered using a panel cointegrated autoregressive distributed lag model. The main data source for this study is the harmonized individual European Union Labour Force Survey (ELFS) data. The ELFS contains data on employment status, 2-digit International Standard Occupational Classification (ISCO) codes.

The data is annual and covers the period from 2000-2016. Data for years preceding the year 2000 were not available for some of the analysed CEE countries. The data on employment is measured in thousands of persons. It also includes data on total factor productivity which is used as a proxi for technology (Solow, 1956; Ngai and Pissarides, 2007). Total factor productivity shows the efficiency with which labour and capital inputs are used together in the production process. It is measured as a residual. In other words, the part of GDP growth that cannot be explained by changes in labour and capital inputs. This indicator is measured as an index and in annual growth rates. The study admits the limitations of total factor productivity as a measure of technology, but it remains one of closest measures of technology in the face of limited data as also used by Antonelli and Quatraro (2010).

Other variables include real value added and employment. Real value added is measured in millions of Euros and is derived by dividing gross value added by inflation (CPI). Employment data is in thousands of persons and includes employment by occupation and by educational qualifications. All data is annual and taken from Eurostat database covering the period 2000 to 2016 . The data is by occupation for each country. The totals for each skill group in each country are obtained by summing up values for all occupations within the skill group. The data for total factor productivity is obtained from the Organization for Economic Cooperation and Development (OECD) and also covers the period 2000-2016. The occupations used were taken according to the International Standard Classification of Occupations (ISCO-08). This classification provided by International Organization of Labour (ILO) divides the employment pool into Low skill, Middle skill and High skill level occupations. This is based on two main concepts: the nature of work performed and the concept of skill. According to this system of classification, all elementary occupations 
are classified under Low skill. Occupations such as Plant and machine operators and assemblers, clerical support workers, service and sales workers, skilled agriculture, forestry and fishery workers as well as craft and trade related workers are classified under Middle skill. High skill occupations include managers, professionals, technicians and associate professionals

The employment structural changes are analysed also according to the educational attainment or qualification. In particular, the changing shares of highly educated, middle and lowly educated people in the skill level groups are analysed in the period, 2000 to 2016. Highly educated labour consists of people with tertiary level education or higher. Middle level educated labour consists of upper secondary, post-secondary and non-tertiary education. Lowly educated labour is made of labour with education less than primary, primary and lower secondary education.

Employment shares of occupations in each of the skill levels are calculated. Employment share is calculated as the ratio of the total employment of the specific occupation to total employment within CEECs in a particular year. A comparison of changes of employment shares over time is carried out. A negative change in employment share shows a decline in the share of an occupation in terms of employment and vice versa. This approach is applied by several authors in the field including Goos and Manning (2007) as well as Autor and Dorn (2009). The calculation of employment shares helps to answer the first research question which investigates the presence of labour polarization.

The second research question involves investigating the role of technology in the changing employment structure. This is answered by modelling the impact of technology on employment using a cointegrated panel autoregressive distributed lag model (ARDL). The results from the ARDL model provide evidence on the role of technology in the changing employment structure. The relationship between technology and employment is also examined in other studies such as Harrigan et al. (2016) and Vivarelli (2014).

To run the ARDL model, unit root test is first conducted to check for the stationary properties of the data. This is done according to Levin et al. (1992) unit root tests. Test of panel cointegration is also carried out using Kao test (Kao, 1999). The optimal lag lengths are decided using the Akaike Information Criterion (Akaike, 1974). All variables are in logarithms and all the results are generated in STATA version 15.

Following the ARDL to cointegration approach proposed by Pesaran et al. (1999), the existence of long-run relationship is tested using a general ARDL representation. The model estimation is done using the Pooled Mean Group Estimator by Pesaran et al. (1999). The PMG estimator constrains the long-run coefficients to be identical but allows the intercept, short-run coefficients, and error variances to differ across groups (Baltagi and Griffin, 1997). This means that the short-run impact of technology is allowed to vary across the Central and European countries while a common relationship is imposed on the long-run coefficients.

To verify whether PMG estimator is the appropriate method, a Hausman test (Hausman, 1978) is conducted to test the restriction of common slopes in the error correction term in the PMG model. Because the Mean Group (MG) estimator is always consistent, the Hausman test assumes the difference between MG and restricted PMG estimators is not 
significantly different from zero, that the PMG estimator is both consistent and efficient. Following the ARDL to cointegration approach proposed by Pesaran et al. (1999), the existence of long-run relationship is tested using a general ARDL representation of equation (1) as follows:

$$
\begin{aligned}
\Delta \ln Y_{i t} & =\alpha_{i}+\sum_{j=1}^{p} \beta_{j} \Delta \ln Y_{i t-j}+\sum_{j=0}^{q}\left[\theta_{j} \Delta \ln X_{i t-j}+\gamma_{j} \Delta \ln Z_{i t-j}\right]+ \\
& +\phi_{1} \ln Y_{i t-1}+\phi_{2} \ln X_{i t}+\phi_{3} \ln Z_{i t}+\mu_{i t}
\end{aligned}
$$

The symbol $\Delta$ denotes the first-difference operator, $\alpha$ refers to specific fixed effects in a country, $Y_{i t}$ refers to employment in thousands of persons. In measuring low skill employment, this study sums up the employment of the occupations within the low skill category. The same applies to middle skill and high skill in each country, $X_{i t}$ refers to real value added. It is derived by dividing gross value added by inflation in each country as mentioned above, $Z_{i t}$ refers to total factor productivity which is the proxi for technology, $\mu_{i t}$ is the error term. There are three separate models, one for low skill employment, another for middle skill employment and the last for high skill employment. For each of the models, low skill employment, middle skill employment and high skill employment are dependent variables.

All three models have common independent variables which are technology and real value added. The model results show whether both technology and real value added have any significant impact on low skill, middle skill and high skill employment. If there is an impact, then what's the direction of impact (negative or positive) and within what period the impact is felt (short-run or long-run). This study admits the existence of other determinants of employment, but the focus is on real value added and technology.

In equation 1, expressions with summation signs represent short-run dynamics. Long-run elasticities are coefficients of the lagged explanatory variables $\left(\phi_{2}\right.$ and $\left.\phi_{3}\right)$ (multiplied with a negative sign) divided by the coefficient of the lagged dependent variable $\left(\phi_{1}\right)$. The ARDL representation is chosen in two steps: first, the optimal lag structure for each state is chosen using the Akaike information criterion (AIC) and the Bayesian information criterion (BIC); second, the maximum number of lags obtained for each variable is used in the panel model. According to the lag frequencies, the preferred specification is an ARDL $(1,1,3)$ in Low skill model, ARDL $(1,3,1)$ in the Middle skill model and ARDL $(1,5,1)$ in the high skill model. Since the error-correction model (ECM) is an alternative with a general form equivalent to the ARDL model, an error-correction version of the ARDL model pertaining to the variables in equation (1) is specified as follows:

$$
\begin{aligned}
\Delta \ln Y_{i t} & =\alpha_{i}+\sum_{j=1}^{p-1} \beta_{j} \Delta \ln Y_{i t-j}+\sum_{j=0}^{q-1}\left[\theta_{j} \Delta \ln X_{i t-j}+\gamma_{j} \Delta \ln Z_{i t-j}\right]+ \\
& +\delta_{1} \ln Y_{i t-1}+\delta_{2} \ln X_{i t}+\delta_{3} \ln Z_{i t}+\mu_{i t}
\end{aligned}
$$

$i=1 \ldots n, t=1 \ldots T$ where $n$ represents countries and $T$ represents time period, $j$ represents lag periods. 
In equation (2), $\delta_{1}$ is the speed of adjustment parameter; a positive $\delta_{1}$ indicates a divergence, and a negative $\delta_{1}$ indicates convergence towards equilibrium. In the ECM, the speed of adjustment parameter and the short-run coefficient estimates (coefficient estimates of all lagged first-differenced variables: $\beta_{j}, \theta_{j}$, and $\gamma_{j}$ ) are directly estimated, and the longrun elasticities are calculated as $-\frac{\delta_{2}}{\delta_{1}}$ and $-\frac{\delta_{3}}{\delta_{1}}$. The long-run coefficients $\left(\delta_{1}, \delta_{2}, \delta_{3}\right)$ are constrained to be equal across countries but short-run coefficients $\left(\beta_{j}, \theta_{j}, \gamma_{j}\right.$ and $\alpha_{i}$ ) are allowed to differ. The study expects a positive relationship between technology and employment in general $(\theta>0)$. For employment in high skill and low skill, the study expects a positive relationship with technology $(\theta>0)$. A negative relationship between employment and technology is expected in middle skill $(\theta<0)$. The study expects a positive relationship between real value added and employment in each of the skill groups $(\gamma>0)$. The results of the ARDL model are discussed in subsequent sections.

\section{Results}

This section discusses the results of the study and gives answers to the research questions. It seeks to find more information on the presence of labour polarization in Central and Eastern Europe and shows whether, technology plays a role in the changing employment structure. Labour polarization is a global phenomenon and is more endemic in developed or advanced countries. Figure 1 shows the situation in the United States of America (U.S.A) and Central and Eastern Europe. The data covers the period from 2000 to 2016 and is in thousands of persons. Figure 1 in the case of USA, shows changes in employment shares of economic activities. The values are in percentages. A negative value shows a decline in employment share and vice versa. Middle skill activities (Skilled Agriculture, Manufacturing and Industry) are clearly seen to be declining in terms of employment shares while high skill (Professionals) and low skill (Construction) increase in employment. Similar results about U.S.A are found in the works of Goos et al. (2014) as well as Acemoglu and Restrepo (2017). Given the evidence of job polarization in U.S.A and other advanced countries, this study seeks to investigate the case of Central and Eastern European countries.

Figure 1: Job polarization in USA and CEEC, 2000-2016
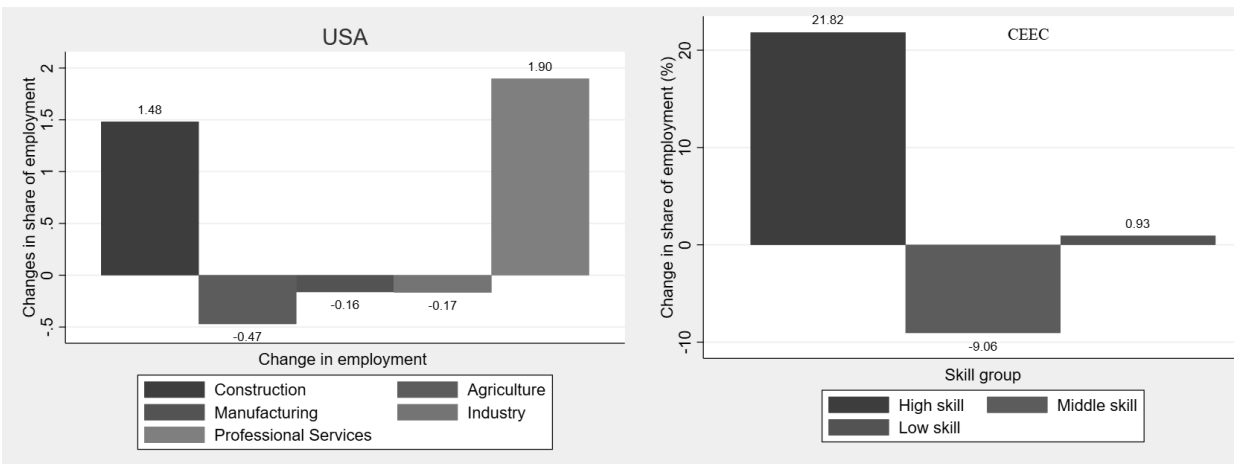

Source: Generated by authors using data from the Bureau of Labour Statistics 
In the same Figure 1, the case of labour polarization in CEEC, is measured using skill groups. Occupations are used for CEEC unlike USA where economic activities are used because the data for occupations which make up the skill groups are reliable and easily available for the period covered by the study. High skill comprises managers, professionals and technicians. Middle skill comprises clerirical and support workers, sales and service workers, skill agriculture, forestry and fishery, craft and related trade workers, as well as plant and machine operators. Low skill comprises elementary occupations. The results show that the employment share of high skill occupations increased by $21.83 \%$. The employment shares of middle skill occupations decreased by $9.06 \%$. The last but not the least is the employment share of low skill occupations which increased slightly by $0.93 \%$.

\section{Changes in Employment Shares of Occupations in CEEC}

Figure 2 shows the changes in employment shares of occupations in Central and Eastern Europe. Values are in percentages. The shares of employment are calculated between the years 2000 and 2016.

Figure 2: Employment performance by occupations in CEEC, 2000-2016

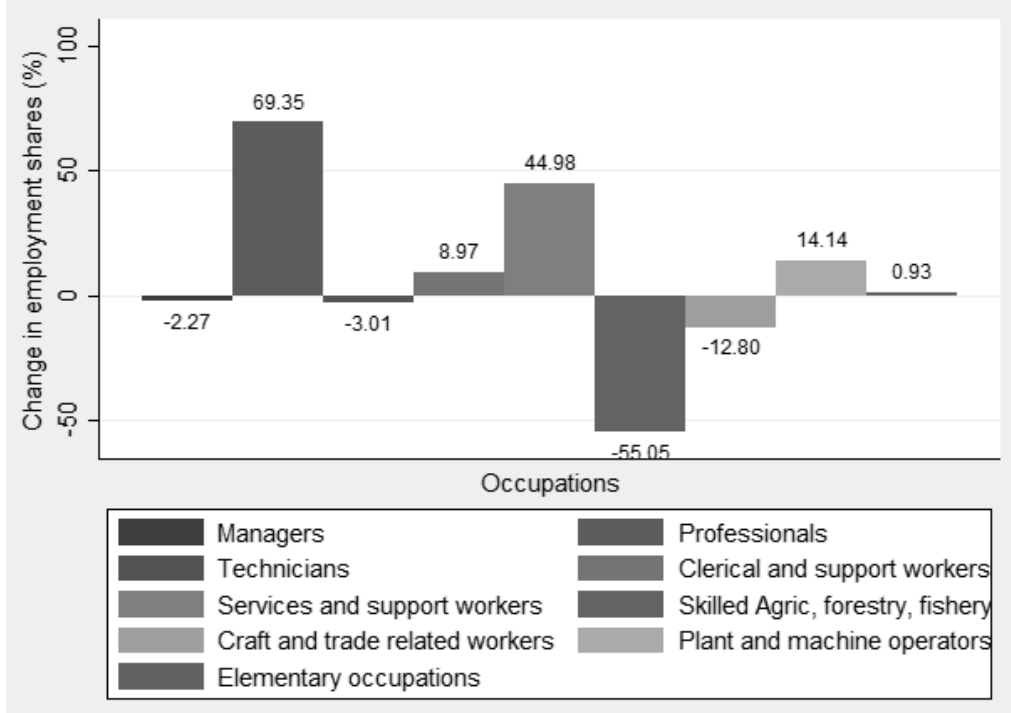

Source: Generated by authors using data from the Bureau of Labour Statistics

The results show that out of three high skill occupations, only professionals experience an increase in their employment share. Both managers and technicians declined. The large increase in employment of professionals however offsets the decrease in employment shares of managers and technicians. For middle skill occupations, clerical support workers, sales and service workers as well as plant and machine operators experienced an increase in their employment share between 2000 and 2016. Skilled agriculture, forestry and fishery 
as well as craft and related trade workers experienced declines in their employment shares. Thus, services occupations in middle skill category increased in employment shares even though large decreases in skilled agriculture, forestry and fishery as well as craft and trade related workers tend to cause an overall decrease in middle skill employment. Low skill occupations which comprise elementary occupations experienced a slight rise in their employment share.

\section{Employment Trend of Labour by Educational Qualification within skill groups}

Labour has different levels of qualifications according to education. This study considers three levels: highly educated, middle educated and lowly educated. Let's recall that highly educated labour consists of people with tertiary level education or higher. Middle level educated labour consists of upper secondary, post-secondary and non-tertiary education. Lowly educated labour is made of labour with education less than primary, primary and lower secondary education. The employment shares of highly educated, middle educated and lowly educated labour in each skill group is estimated for all the CEEC Countries in total between the period 2000-2016. For example, there is a given number of highly educated labour in high skill occupations.

Similarly, there are couple of middle educated labour in high skill occupations. It is therefore necessary to look at the composition of labour in each skill group. Figure 3 shows the case of highly educated and middle educated labour in high skill, middle skill and low skill occupations. It is observed that the number of highly educated workers in high skill occupations is growing. The number of highly educated workers in middle skill jobs is also growing. The number of highly educated labour in low skill occupations is steady.

Figure 3: Labour in skill groups by education, CEEC


Source: Generated by authors using data from Eurostat

It is also observed in Figure 3, that the percentage of middle educated labour in high skill occupations is declining. Middle educated labour includes labour with upper secondary, post-secondary and non-tertiary education. Their employment in low skill occupations is rising. Middle educated labour in middle skill occupations is rising steadily. The declining percentage of middle educated labour in high skill occupations might be indicative of 
educational transformation of such class of labour into high skill. It could also indicate that the higher demands of high skill tasks reduce the attractiveness of middle skill labour in high skill occupations. The displacement effect of technology in the middle skill category is therefore offset by employment opportunities in low skill category.

Figure 4 shows the employment of lowly educated labour in other occupations. Lowly educated labour consists of labour with education less than primary, primary and lower secondary education. It is observed that the employment of labour with low education in middle skill occupations is declining sharply. Their employment in low skill occupations also declines marginally. Lowly educated labour declining in middle skill occupations is normal due to the requirements of tasks in middle skill category. Lowly educated labour declining in low skill occupations could have several meanings. Either the labour in this category is going for higher education to move to higher skilled jobs which is less likely or there is a decline in total employment of low skill labour (with gently rising share of middle educated as shown in Figure 3). It could also be attributed to the growing presence of middle educated labour in low skill occupations.

Figure 4: Lowly educated labour in other skill occupations, CEEC



Source: Generated by authors using data from Eurostat

\section{The Effect of Technology on Employment in Skill Groups}

This part explains using panel ARDL model the relationship between technological transition and changes in employment in the different skill groups. The model seeks to find out the impact of technology on the changing employment structure in Central and Eastern Europe. In other words, to investigate whether technology has a positive or negative impact on employment within the skill groups. The results of the model start with the Hausman test and later the results of the panel autoregressive distributed lag model. 


\section{Hausman test of MG and PMG}

The study uses the Hausman (1978) test to show that the restriction of long-run parameters (PMG) gives efficient results. The null hypothesis of this Hausman test is an assumption of long-run slope homogeneity. A failure to reject the null hypothesis of long-run slope homogeneity shows that PMG is the appropriate estimator for the study. Related to this study, the Hausman test helps to confirm the fact that a common long-run impact of technology can be imposed on Central and Eastern European countries while allowing the impact to differ from country to country in the short-run.

Table 1: Results of Hausman test of mean group and pooled mean group models

\begin{tabular}{|c|c|c|c|c|}
\hline \multicolumn{5}{|c|}{ Low sill employment } \\
\hline \multirow[t]{2}{*}{ Variable } & (b) & $(B)$ & $(b-B)$ & $\operatorname{sqrt}\left(\operatorname{diag}\left(V_{-} b-V_{-} B\right)\right)$ \\
\hline & MG & PMG & difference & S.E. \\
\hline Log GVA(L1.) & 0.907 & 1.151 & -0.244 & 0.469 \\
\hline Log TFP (L1.) & -2.422 & -3.569 & 1.147 & 3.926 \\
\hline $\begin{array}{l}\text { Chi2 }(2)= \\
=(b-B)^{\prime}\left[\left(V_{-} b-V_{-} B\right)^{\wedge}(-1)\right](b-B)\end{array}$ & \multicolumn{3}{|l|}{$\mathrm{P}$ value } & \\
\hline 0.4 & \multicolumn{3}{|l|}{0.821} & \\
\hline \multicolumn{5}{|c|}{ Middle skill employment } \\
\hline \multirow[t]{2}{*}{ Variable } & (b) & $(B)$ & $(b-B)$ & $\operatorname{sqrt}\left(\operatorname{diag}\left(V_{-} b-V_{-} B\right)\right)$ \\
\hline & MG & PMG & difference & S.E. \\
\hline Log GVA(L1.) & 0.228 & 0.428 & -0.200 & 0.090 \\
\hline Log TFP (L1.) & -0.444 & -1.149 & 0.705 & 0.580 \\
\hline $\begin{array}{l}\text { Chi2 } 2(2)= \\
=(b-B)^{\prime}\left[\left(V_{-} b-V_{-} B\right)^{\wedge}(-1)\right](b-B)\end{array}$ & \multicolumn{3}{|l|}{$\mathrm{P}$ value } & \\
\hline 4.94 & \multicolumn{3}{|l|}{0.085} & \\
\hline \multicolumn{5}{|c|}{ High skill employment } \\
\hline \multirow[t]{2}{*}{ Variable } & $(b)$ & $(B)$ & $(b-B)$ & $\operatorname{sqrt}\left(\operatorname{diag}\left(V_{-} b-V_{-} B\right)\right)$ \\
\hline & MG & PMG & difference & S.E. \\
\hline Log GVA(L1.) & 0.009 & 0.205 & -0.197 & 0.273 \\
\hline Log TFP (L1.) & 1.470 & 1.155 & 0.315 & 2.923 \\
\hline $\begin{array}{l}\text { Chi2 }(2)= \\
=(b-B)^{\prime}\left[\left(V_{-} b-V_{-} B\right)^{\wedge}(-1)\right](b-B)\end{array}$ & $P$ value & & & \\
\hline 4.94 & 0.085 & & & \\
\hline
\end{tabular}

Note: $b=$ consistent under Ho and Ha; obtained from xtpmg, B = inconsistent under Ha, efficient under Ho; obtained from xtpmg, Test: Ho: difference in coefficients not systematic, L1 represents lag 1, sqrt (square root)

Source: Generated by authors using STATA 15 
The results for Hausman test of long-run slope homogeneity can be seen in Table 1. The results are in three categories because of the three different models for low skill employment, middle skill employment and high skill employment. It is observed that the $p$ values for all the Hausman tests are greater than the significance level of 0.05 indicating that the pooled mean group (PMG) is appropriate. That means that in the panel ARDL model, the long-run effects of real value added, and technology are pooled across the Central and Eastern European countries and restricted to individual country effects in the short-run.

\section{The impact of technology on low skill employment}

The results from ARDL model of low skill employment in Table 2 shows that technology has negative impact on employment of low skill employment in the long-run. The shortrun effects vary according to countries and lag distributions. Thus, growing technological progress leads to declining employment of low skill workers. The speed with which each country adjusts to long-run equilibrium varies. The error correction term is negative and highly significant. $56 \%$ of deviation from long-run equilibrium in Bulgaria, $11 \%$ in Hungary, $74 \%$ in Poland, $54 \%$ in Romania and 25\% in Slovakia are corrected in one period. The positive coefficient for speed of adjustment in the Czech Republic shows divergence from equilibrium. The long-run coefficients are interpreted as elasticities. Technology has a negative impact on low skill employment, and it is highly elastic meaning that low skill employment is very responsive to technological innovation. It is however worth mentioning that the category of low skill jobs that are routine in nature will be easily replaced by technology.

Table 2: Impact of Technology on employment of low skill labour

\begin{tabular}{|l|r|r|r|r|r|r|r|}
\hline VARIABLES & ECT & Bulgaria & Czech R & Hungary & Poland & Romania & Slovakia \\
\hline ECT & & $-0.559 * *$ & $0.161 * *$ & $-0.109 * *$ & $-0.739 * * *$ & $-0.543 * * *$ & $-0.252 * *$ \\
& & $(0.272)$ & $(0.090)$ & $(0.043)$ & $(0.135)$ & $(0.157)$ & $(0.109)$ \\
\hline D.Ln low skill & & $-0.68^{* *}$ & $-0.198 * * *$ & $-0.56 * *$ & $-0.39 * * *$ & $-0.18^{* * *}$ & $-0.80 * *$ \\
& & $(0.012)$ & $(0.002)$ & $(0.011)$ & $(0.009)$ & $(0.007)$ & $(0.091)$ \\
\hline D.ln GVA & & -0.050 & -0.063 & -0.038 & 0.002 & 0.055 & 0.167 \\
& & $(0.246)$ & $(0.056)$ & $(0.080)$ & $(0.042)$ & $(0.070)$ & $(0.183)$ \\
\hline D.ln TFP & & -0.999 & $1.007 * * *$ & $4.704 * *$ & $2.433 * * *$ & $1.600 * * *$ & 1.168 \\
& & $(2.002)$ & $(0.390)$ & $(1.915)$ & $(0.706)$ & $(0.523)$ & $(0.852)$ \\
\hline D2.ln TFP & & -0.975 & -0.521 & $-4.181 * * *$ & $-3.417 * * *$ & $-2.555 * * *$ & -1.384 \\
& & $(2.171)$ & $(0.539)$ & $(1.531)$ & $(0.918)$ & $(0.796)$ & $(1.126)$ \\
\hline D3.ln TFP & & 0.513 & 0.079 & $1.742 * * *$ & $0.831 * * *$ & $0.917 * * *$ & -0.115 \\
& & $(0.739)$ & $(0.260)$ & $(0.676)$ & $(0.321)$ & $(0.352)$ & $(0.531)$ \\
\hline
\end{tabular}




\begin{tabular}{|l|r|r|r|r|r|r|r|}
\hline VARIABLES & \multicolumn{1}{c|}{ ECT } & Bulgaria & Czech R & Hungary & Poland & Romania & Slovakia \\
\hline L.ln GVA & $\begin{array}{r}0.211^{* * *} \\
(0.068)\end{array}$ & & & & & & \\
\hline L.ln TFP & $\begin{array}{r}-2.882 * * * \\
(0.219)\end{array}$ & & & & & & \\
\hline Constant & & $1.617 *$ & -0.428 & $0.267 *$ & $2.515 * * *$ & $1.890 * *$ & 0.280 \\
& & $(0.869)$ & $(0.306)$ & $(0.142)$ & $(0.802)$ & $(0.837)$ & $(0.280)$ \\
\hline Observations & 72 & 72 & 72 & 72 & 72 & 72 & 72 \\
\hline
\end{tabular}

Note: The maximum number of lags for each variable was set to five. The optimal lag lengths were decided using the Akaike Information Criterion. The PMG estimators were computed by iterations obtained from xtpmg. Standard errors in parentheses, $* * * p<0.01, * * p<0.05, * p<0.1$, Standard errors in parentheses, $* * * p<0.01, * * p<0.05, * p<0.1$, Standard errors in parentheses, $* * *$ $p<0.01, * * p<0.05, * p<0.1, D, D 2, D 3 \ldots$ Dn represent lags of first order difference variables. The variable $L$ represents long-run, ECT (error correction term).

Source: Generated by authors using STATA 15

\section{The impact of technology on middle skill employment}

The results from ARDL model of low skill employment in Table 3 shows that technology has negative impact on employment of middle skill employment in the long-run. The shortrun effects vary according to countries and lag distributions. Thus, growing technological progress leads to declining employment of middle skill workers. This is largely due to the fact that several occupations within middle skill category are routine biased hence easily replaceable by technology. The speed with which each country adjusts to long-run equilibrium varies. The error correction term is negative and highly significant. The speed of adjustment to long equilibrium faster in Bulgaria with about $100 \%$ of deviation from equilibrium corrected in one period. Then $21 \%$ in the Czech Republic, 39\% in Hungary, $37 \%$ in Poland, $16 \%$ in Romania and $20 \%$ in Slovakia are corrected annually. The long-run coefficients are interpreted as elasticities. And for all the countries elasticity is higher than 1 indicating that middle skill employment is highly elastic to technological progress.

Table 3: Impact of Technology on middle skill labour

\begin{tabular}{|l|r|r|r|r|r|r|r|}
\hline \multicolumn{1}{|c|}{ VARIABLES } & ECT & Bulgaria & Czech R & Hungary & Poland & Romania & Slovakia \\
\hline ECT & & $-1.060 * * *$ & $-0.209 * *$ & $-0.387 * *$ & $-0.372 * * *$ & $-0.163 * * *$ & $-0.195 * *$ \\
& & $(0.210)$ & $(0.085)$ & $(0.021)$ & $(0.096)$ & $(0.051)$ & $(0.012)$ \\
\hline D.ln Middle Skill & & $-0.125 * *$ & $-0.190 * * *$ & $-0.0170 * *$ & $-0.390 * * *$ & $-0.220 * *$ & $-0.160 * *$ \\
& & $(0.055)$ & $(0.018)$ & $(0.055)$ & $(0.004)$ & $(0.019)$ & $(0.032)$ \\
\hline
\end{tabular}




\begin{tabular}{|c|c|c|c|c|c|c|c|}
\hline VARIABLES & ECT & Bulgaria & Czech R & Hungary & Poland & Romania & Slovakia \\
\hline D.ln GVA & & $\begin{array}{r}1.441 * * * \\
(0.243)\end{array}$ & $\begin{array}{r}-0.292 * * * \\
(0.112)\end{array}$ & $\begin{array}{c}0.657^{*} \\
(0.350)\end{array}$ & $\begin{array}{r}0.492 * * * \\
(0.062)\end{array}$ & $\begin{array}{r}0.224 * * * \\
(0.057)\end{array}$ & $\begin{array}{r}0.470 * * \\
(0.191)\end{array}$ \\
\hline D2.ln GVA & & $\begin{array}{r}-1.152 * * * \\
(0.286)\end{array}$ & $\begin{array}{r}0.446 * * * \\
(0.159)\end{array}$ & $\begin{array}{l}-0.525 \\
(0.339)\end{array}$ & $\begin{array}{r}-0.308 * * * \\
(0.072)\end{array}$ & $\begin{array}{l}-0.053 \\
(0.069)\end{array}$ & $\begin{array}{l}-0.051 \\
(0.230)\end{array}$ \\
\hline D3.ln GVA & & $\begin{array}{r}0.473 * * * \\
(0.150)\end{array}$ & $\begin{array}{r}-0.486 * * * \\
(0.105)\end{array}$ & $\begin{array}{r}0.193 \\
(0.134)\end{array}$ & $\begin{array}{r}0.034 \\
(0.040)\end{array}$ & $\begin{array}{l}-0.066 \\
(0.041)\end{array}$ & $\begin{array}{l}-0.071 \\
(0.105)\end{array}$ \\
\hline D.ln TFP & & $\begin{array}{l}-0.006 \\
(0.011)\end{array}$ & $\begin{array}{r}-0.161 * * * \\
(0.034)\end{array}$ & $\begin{array}{r}0.014 \\
(0.050)\end{array}$ & $\begin{array}{l}-0.015 \\
(0.018)\end{array}$ & $\begin{array}{r}-0.038 * * * \\
(0.013)\end{array}$ & $\begin{array}{r}0.006 \\
(0.021)\end{array}$ \\
\hline L. In GVA & $\begin{array}{r}0.368 * * * \\
(0.065)\end{array}$ & & & & & & \\
\hline L.ln TFP & $\begin{array}{r}-0.719 * * * \\
(0.187) \\
\end{array}$ & & & & & & \\
\hline Constant & & $\begin{array}{r}3.588 * * * \\
(0.736)\end{array}$ & $\begin{array}{c}0.613 * \\
(0.325)\end{array}$ & $\begin{array}{r}1.246 \\
(0.839)\end{array}$ & $\begin{array}{r}1.589 * * * \\
(0.464)\end{array}$ & $\begin{array}{r}0.607 * * \\
(0.261)\end{array}$ & $\begin{array}{r}0.589 \\
(0.432)\end{array}$ \\
\hline Observations & 72 & 72 & 72 & 72 & 72 & 72 & 72 \\
\hline \multicolumn{8}{|c|}{$\begin{array}{l}\text { Standard errors in parentheses } \\
* * * p<0.01, * * p<0.05, * p<0.1\end{array}$} \\
\hline
\end{tabular}

Note: The maximum number of lags for each variable was set to five. The optimal lag lengths were decided using the Akaike Information Criterion. The PMG estimators were computed by iterations obtained from xtpmg. Standard errors in parentheses, $* * * p<0.01, * * p<0.05, * p<0.1$, Standard errors in parentheses, $* * * p<0.01, * * p<0.05, * p<0.1$, Standard errors in parentheses, $* * *$ $p<0.01$, ** $p<0.05, * p<0.1, D, D 2, D 3 \ldots$ Dn represent lags of first order difference variables. The variable L represents long-run, ECT (error correction term).

Source: Generated by authors using STATA 15

\section{The impact of technology on high skill employment}

The results from ARDL model of high skill employment in Table 4 shows that technology has a positive impact on employment of high skill in the long-run and elasticity of high skill employment to changes in technology is higher than 1 for all countries. The short-run effects vary according to countries and lag distributions. Thus, growing technological progress leads to growing employment of high skill workers. The speed with which each country adjusts to long-run equilibrium varies. The error correction term is negative and highly significant. The case of Bulgaria shows divergence from long-run equilibrium as the coefficient is great than 1.92\% in the Czech Republic, 55\% in Hungary, $85 \%$ in Poland, $38 \%$ in Romania, $97 \%$ in Slovakia are corrected annually. 
DANUBE: Law, Economics and Social Issues Review, 11 (1), 52-74

DOI: 10.2478/danb-2020-0004

Table 4: Impact of Technology on high skill labour

\begin{tabular}{|c|c|c|c|c|c|c|c|}
\hline VARIABLES & ECT & Bulgaria & Czech R & Hungary & Poland & Romania & Slovakia \\
\hline ECT & & $\begin{array}{c}0.100 * * \\
(0.0145)\end{array}$ & $\begin{array}{r}-0.923 * * * \\
(0.138)\end{array}$ & $\begin{array}{r}-0.55 * * * \\
(0.034)\end{array}$ & $\begin{array}{r}-0.850 * * * \\
(0.180)\end{array}$ & $\begin{array}{r}-0.383 * * * \\
(0.060)\end{array}$ & $\begin{array}{r}-0.969 * * * \\
(0.268)\end{array}$ \\
\hline D.ln High skill & & $\begin{array}{r}-0.124 * * \\
(0.048)\end{array}$ & $\begin{array}{r}-0.48 * * \\
(0.020)\end{array}$ & $\begin{array}{r}-0.21 * * \\
(0.020)\end{array}$ & $\begin{array}{r}-0.47 \\
(0.029)\end{array}$ & $\begin{array}{r}-0.50 * * * \\
(0.003)\end{array}$ & $\begin{array}{r}-0.70 * * \\
(0.036)\end{array}$ \\
\hline D.ln GVA & & $\begin{array}{l}-0.551 \\
(0.429)\end{array}$ & $\begin{array}{r}1.053 * * * \\
(0.169)\end{array}$ & $\begin{array}{r}-0.301 * * * \\
(0.104)\end{array}$ & $\begin{array}{r}0.194 \\
(0.180)\end{array}$ & $\begin{array}{r}0.279 * * * \\
(0.029)\end{array}$ & $\begin{array}{r}-1.834 * * * \\
(0.550)\end{array}$ \\
\hline D2.ln GVA & & $\begin{array}{r}1.585 * * * \\
(0.597)\end{array}$ & $\begin{array}{r}-2.725 * * * \\
(0.487)\end{array}$ & $\begin{array}{r}0.948 * * * \\
(0.302)\end{array}$ & $\begin{array}{l}-0.257 \\
(0.273)\end{array}$ & $\begin{array}{r}-0.196 * * * \\
(0.068)\end{array}$ & $\begin{array}{r}4.396 * * * \\
(1.443)\end{array}$ \\
\hline D3.ln GVA & & $\begin{array}{r}-2.030 * * \\
(0.798)\end{array}$ & $\begin{array}{r}3.312 * * * \\
(0.693)\end{array}$ & $\begin{array}{r}-0.768 * * \\
(0.385)\end{array}$ & $\begin{array}{r}0.416 \\
(0.283)\end{array}$ & $\begin{array}{r}0.617 * * * \\
(0.094)\end{array}$ & $\begin{array}{r}-3.966 * * * \\
(1.366)\end{array}$ \\
\hline D4.ln GVA & & $\begin{array}{c}1.143 * \\
(0.592)\end{array}$ & $\begin{array}{r}-1.655^{* * * *} \\
(0.420)\end{array}$ & $\begin{array}{r}0.163 \\
(0.222)\end{array}$ & $\begin{array}{l}-0.215 \\
(0.150)\end{array}$ & $\begin{array}{r}-0.804 * * * \\
(0.070)\end{array}$ & $\begin{array}{r}1.916 * * * \\
(0.691)\end{array}$ \\
\hline D5.ln GVA & & $\begin{array}{l}-0.237 \\
(0.189)\end{array}$ & $\begin{array}{r}0.311 * * * \\
(0.098)\end{array}$ & $\begin{array}{r}0.001 \\
(0.052)\end{array}$ & $\begin{array}{r}0.041 \\
(0.034)\end{array}$ & $\begin{array}{r}0.298 * * * \\
(0.021)\end{array}$ & $\begin{array}{r}-0.389 * * * \\
(0.142)\end{array}$ \\
\hline D.TFP & & $\begin{array}{l}-0.176 \\
(0.300)\end{array}$ & $\begin{array}{r}1.634 * * * \\
(0.356)\end{array}$ & $\begin{array}{r}0.010 \\
(0.185)\end{array}$ & $\begin{array}{r}1.100 * * * \\
(0.319)\end{array}$ & $\begin{array}{r}-0.440 * * * \\
(0.090)\end{array}$ & $\begin{array}{r}0.964 * * \\
(0.442)\end{array}$ \\
\hline L.ln GVA & $\begin{array}{r}0.213 * * * \\
(0.025) \\
\end{array}$ & & & & & & \\
\hline L.TFP & $\begin{array}{r}2.560 * * * \\
(0.181) \\
\end{array}$ & & & & & & \\
\hline Constant & & $\begin{array}{l}-0.197 \\
(0.358)\end{array}$ & $\begin{array}{r}3.320 * * * \\
(0.484)\end{array}$ & $\begin{array}{c}0.201 * \\
(0.103)\end{array}$ & $\begin{array}{r}3.220 * * * \\
(0.679)\end{array}$ & $\begin{array}{r}1.290 * * * \\
(0.224)\end{array}$ & $\begin{array}{r}2.214 * * * \\
(0.606)\end{array}$ \\
\hline Observations & 72 & 72 & 72 & 72 & 72 & 72 & 72 \\
\hline \multicolumn{8}{|c|}{ Standard errors in parentheses } \\
\hline
\end{tabular}

Note: The maximum number of lags for each variable was set to five. The optimal lag lengths were decided using the Akaike Information Criterion. The PMG estimators were computed by iterations obtained from xtpmg. Standard errors in parentheses, $* * * p<0.01, * * p<0.05, * p<0.1$, Standard errors in parentheses, $* * * p<0.01, * * p<0.05, * p<0.1$, Standard errors in parentheses, $* * *$ $p<0.01, * * p<0.05, * p<0.1, D, D 2, D 3 \ldots$ Dn represent lags of first order difference variables. The variable $L$ represents long-run, ECT (error correction term).

Source: Generated by authors using STATA 15 
The models were checked for autocorrelation, normality and heteroskedasticity. The results showed that they were no such problems. Bounds testing was carried out to verify the existence of a long-run relationship among the variables in the models. The F statistic obtained from the wald tests for all the models are greater than the upper bound of the bounds test indicating that the variables have a long-run relationship in the three models.

\section{Discussion}

This section discusses and compares the findings of this study with the findings of other existing studies. The results from this study show a decline in the share of employment of middle skill occupations. The study also observes a rise in employment shares of high and low skill category.

\section{Is Job Polarization Observed in Central and Eastern Europe?}

The study uses changes in employment shares and line plots to investigate whether there is job polarization or not. Changes in employment shares differ from one occupation to the other. The results show that the overall share of employment of high skill increased. The employment share of middle skill decreased while low skill increases slightly. Even though both high skill and low skill employment is rising, the rise in low skill employment is very small to lead to a U-shape employment distribution which indicates labour polarization. This study uses the classification of the international labour organization. Technology might be the cause of falling employment in middle skill category but that remains to be proven because there are other determinants of employment. Even though middle skill employment is declining, the distribution of employment in terms of high, middle and low skill is not $\mathrm{U}$-shape to warrant the conclusion of polarization.

Results of within skill group labour movement show that there is a declining number of middle educated labour in high skill occupations. There is however a slight rise in the presence of middle educated labour in low skill occupations. The overall employment share of middle educated labour in middle skill category remains steady which is explained by the fact that some occupations within the middle skill category increased in employment share thus creating more opportunities for the displaced middle educated labour from other middle skill occupations. Displaced middle educated labour from middle skill occupations might also be moving to low skill occupations thus accounting for the growing presence of middle educated labour in low skill category.

Even though middle skill employment decreased, employment in services within the middle skill category (Clerical support workers as well as Service and sales workers) increased. Thus, the decrease in middle skill employment is largely attributed to the decline in employment of the more routine activities (skilled agriculture, forestry and fishery as well as craft and trade related workers).

The findings of this study are similar to that of Levy and Murnane (2005) who conclude that, the major consequence of computerization will not be mass unemployment but a continued decline in the demand for moderately-skilled and less-skilled labour. They 
stressed that job opportunities will grow, but the growth will be more imminent in high skill occupations in which computers complement expert thinking and complex communication to produce new products and services.

The results of this study are also similar to Rotman (2013) and Deane (2013) who conclude that while the evidence is only suggestive and not conclusive on the role of technology in the changing employment structure, growth in the use of machines significantly affects employment causing a decline in middle skill jobs and rise in low and high skill jobs.

This study finds that, the employment share of highly educated workers in high skill and middle skill occupations is growing; the number of highly educated labour in low skill occupations is steady. The study also observes that, the share of middle educated labour in high skill occupations is declining whiles their employment share in low skill occupations is rising. Middle educated labour in middle skill occupations is also rising steadily.

The declining share of middle educated labour in high skill occupations might be indicative of educational transformation of such class of labour into high skill. It could also indicate that the higher demands of high skill tasks reduce the attractiveness of middle skill labour in high skill occupations. The displacement effect of technology in the middle skill category is therefore offset by employment opportunities in low skill category.

The findings of this study suggest that even though middle skill jobs decline, there is inconclusive evidence to show that overall employment in Central and Eastern Europe will decline. Low skill and high skill jobs grew, and such a growth can make up for the decline in middle skill jobs. This finding is in line with the findings of (Bruckner et al., 2017) who conclude that technologies replace certain tasks rather than all jobs and new technologies often create new jobs.

\section{What is the Role of Technology in the Changing Employment Structure?}

Technological change and offshoring have been suggested as the main drivers of polarisation of labour markets and studies comparing the explanatory power of the two generally conclude that the latter is more important (Acemoglu and Autor, 2011; Autor and Dorn, 2013). It is however more difficult to measure the impact of offshoring due to lack of data availability. The routine biased technological change (RBTC) hypothesis proposes that technology reduces the relative demand of labour in mid-skill occupations due to the increasing ability of machines to perform easy-to-codify "routine" tasks which characterise these occupations. This study uses a panel cointegrated autoregressive distributed lag model to investigate the impact of technology on employment in Central and Eastern Europe.

The results from the ARDL model show that technology affects employment in all the countries studied. The impact on low and middle skill employment is negative in the long-run but positive on high skill employment. All the six countries in CEEC have elastic responses to changes in technology. Elasticity is greater than 1 in all the countries. The short-run impacts vary across countries and with the lags used. The speed of adjustment to equilibrium differs across the countries and skill groups. The fastest speed of adjustment to long-run equilibrium occurs in the high skill category. Low skill employment has the 
lowest speed of adjustment to equilibrium. The differences observed with regards to the speed of adjustment to changes in technology are similar to the findings of Dachs (2018) who conclude that the speed and dynamism of the impact of technology differ across countries due to differences in the labour markets.

The results are also compared with that of Fonseca et al. (2018) and both findings conclude that technology plays a significant impact on employment. Tüzemen and Willis (2013) in their study also attributed the vanishing middle skill jobs and the growing low and high skill jobs to growing use of technology by firms.

Within-skill group employment changes are often marked as evidence consistent with a pervasive effect of technology (Spitz-Oener, 2006, Acemoglu and Autor, 2011). This study observes that technology plays a role in the changing employment structure but cannot emphatically state that the observed employment distribution is due to only technology since there are many other determinants of employment in the labour market. For example, in the build up to the ARDL model, routine and non-routine tasks are bundled together within the same skill group making it difficult to predict the impact of technology across skill groups just as the findings of Autor and Dorn (2013). In addition, the heterogeneity of employment patterns across countries and over time suggests that factors other than technology continue to play a significant role.

This paper concludes that changes in the occupational structure of the Central and Eastern Europe labour market over the past 20 years cannot be understood as being dominated by RBTC alone. Growing demand for education has contributed significantly to the main feature of the changing employment process. In other words, the substantial reallocation of employment from middling to top occupations can be attributed to demand by labour for high education.

While in the US employment growth has gradually favoured low skill occupations, in Central and Eastern Europe growth at the top has exceeded that at the bottom as observed in the findings of this study. The high growth in high skill employment and the sharp decline in middle skill employment could be indicative of the gain top occupations have made from the employment shares lost by middling ones.

This study observes that even though the employment structure is changing there is no clear case of decreased employment of labour in totality. In other words, increasing digitalization or technological innovation might not necessarily cause an increase in unemployment in Central and Eastern Europe and this is similar to the findings of Davis and Haltiwanger (2014) and Atkinson et al. (2010).

\section{Conclusion}

The study seeks to investigate the changing employment structures in Central and Eastern Europe specifically, Bulgaria, Czech Republic, Hungary, Poland, Romania and Slovakia and to ascertain whether job polarization occurs. The study also investigates the role of technology in the changing employment structure using a panel cointegrated ARDL model. The results do not present a clear U-shape employment distribution to indicate job polarization in Central and Eastern Europe. 
Middle skill employment decreased in share while high skill and low skill employment increased. Even though middle skill employment declined as a whole, middle skill service occupations increased in terms of employment. These include clerical support workers as well as service and sales workers. Their impact was however offset by the decline in employment from skilled agriculture, forestry and fishery workers as well as craft and trade related workers which are the two occupations with large employment effect within the middle skill category. This is in line with the expectation that, the role of services will be growing in societies with rising role of high skilled labour. In developed countries, the role of services is expected to grow since the middle and low skill activities tend to be offshored by the high-tech firms as well as high skill households.

This study considers three levels of labour educational qualification: highly educated, middle educated and lowly educated. The findings from this study show that there is a decline in the share of middle educated labour in high skill occupations. The share of middle educated labour in low skill occupations however rose slightly. The share of middle educated labour in middle skill occupations remained steady and this is explained by the fact that some occupations within the middle skill category increased in employment share thus creating more opportunities for the displaced middle educated labour from other middle skill occupations. Displaced middle educated labour from middle skill occupations might also be moving to low skill occupations thus accounting for the growing presence of middle educated labour in low skill category.

Using the ARDL model, the study establishes that technology has an impact on employment in Central and Eastern Europe. The study observes that, the impact of technology on high skill employment is positive in the long-run but negative on low and middle skill employment. The short-run impacts vary across countries and with the lags used.

The study also observes that the speed of adjustment to equilibrium differs across the countries and skill groups. The fastest speed of adjustment to long-run equilibrium occurs in the high skill category. Even though this study establishes a relationship between technology and employment in the various skill levels, this study does not attribute the observed employment distribution to only the influence of technology. There are other factors that influence employment and all those factors should be taken into consideration to make a comprehensive conclusion about the cause of the employment distribution in Central and Eastern Europe.

Observing the level of total employment in Central and Eastern Europe over the period under study, there is no clear decline in total employment even though employment in some skill groups declined. This proves that increasing digitalization or technological innovation might not necessarily cause an increase in unemployment given that labour displaced by technology takes advantage of job opportunities in other skill groups within Central and Eastern Europe.

This paper concludes that changes in the occupational structure of the CEEC's labour market over the past years cannot be solely attributed to RBTC. There is high growing demand for education and that has contributed significantly to the changes in employment process. 


\section{References}

Acemoglu, D. and Autor, D. H. (2011). Skills, tasks and technologies: implications for employment and earnings. Handbook of Labour Economics, 1043-1171.

Acemoglu, D. and Restrepo, P. (2017). Robots and jobs: evidence from us labour markets. NBER Working Paper, No. 23285, Cambridge, MA, National Bureau of Economic Research.

Adermon, M. G. (2015). Job polarization and task-biased technological change: evidence from Sweden, 1975-2005. The Scandinavian Journal of Economics, 117(3), 878-917.

Akaike, H. (1974). A new look at the statistical model identification. IEEE Transactions on Automatic Control, 19 (6), 716-723.

Antonelli, C. and Quatraro, F. (2010). The effects of biased technological change on total factor productivity. empirical evidence from a sample of OECD countries. Journal of Technology Transfer, Springer Verlag, 35, 361-383.

Atkinson, A. B., Piketty, T. and Saez, E. (2010). Top incomes in the long run of history. Journal of Economic Literature, 49(1), 3-71.

Autor, D. (2010). The polarization of job opportunities in the U.S labour market: implications for employment and earnings. Centre for American Progress and the Hamilton Project. Online. Available at: https://economics.mit.edu/files/5554.

Autor, D. H and Dorn, D. (2009). This job is getting old: measuring changes in job opportunities using occupational age structure. American Economic Review, 99(2), 45-51.

Autor, D. H. and Dorn, D. (2013). The growth of low skill service jobs and the polarization of the U.S. labour market. American Economic Review, 103(5), 1553-1597.

Autor, D. H., Kartz, L. F. and Kearnery S. M. (2006). The polarization of the US labour market. American Economic Review, 96(2), 189-94.

Autor, D. H., Levy, F, and Murnane, R. J. (2003). The skill-content of recent technological change: an empirical investigation. Quarterly Journal of Economics, 118(4), 1279-1333. Baker, D. and Hassett, K. (2012). The Human Disaster of Unemployment. New York Times. Online. Available at: https://www.nytimes.com/2012/05/13/opinion/sunday/thehuman-disaster-of-unemployment.html.

Baltagi, B. H., and Griffin, J. M. (1997). Pooled estimators vs. their heterogeneous counterparts in the context of dynamic demand for gasoline. Journal of Econometrics, Elsevier, 77(2), 303-327.

Bernardi, F. and Garrido, L. (2008). Is there a new service proletariat? Post-industrial employment growth and social inequality in Spain. European Sociological Review, 24, 299-313.

Bessen, J. (2013). Don't blame technology for persistent unemployment. Slate, accessed. http://www.slate.com/blogs/future_tense/2013/09/30/technology_isn_t_taking_all_of_our _jobs.html.

Bruckner, M., LaFleur, M., and Pitterle, I. (2017). The impact of the technological revolution on labour markets and income distribution. Online. Available at: https://www.un.org/ development/desa/dpad/wp-content/uploads/sites/45/publication/2017_Aug_Frontier-Issues-1.pdf. 
Brynjolfsson, E. and McAfee. A. (2011). Race against the machine. Lexington, MA: Digital Frontier Press.

Dachs, B. (2018). The impact of new technologies on the labour market and the social economy. European Parliamentary Research Service. Scientific Foresight Unit. Online. Available at: http://www.europarl.europa.eu/RegData/etudes/STUD/2018/614539/EPRS_STU (2018) 614539_EN.pdf.

Davis, S. J. and Haltiwanger, J. (2014). Labour market fluidity and economic performance. NBER Working Paper, No. 20479, Cambridge, MA, National Bureau of Economic Research.

Deane, G. (2013). Technological unemployment: panacea or poison? Institute of ethics and emerging technologies blog, March 5, accessed Oct. 10, 2013, http://ieet.org/index.php/ IEET/more/deane20130305.

Dustmann, C., Ludsteck, J. and Schonberg, U. (2009). Revisiting the German wage structure. Quarterly Journal of Economics, 124, 843-881.

Fernandez-Martinez J, et al. (2012). Structure-function mapping of a heptameric module in the nuclear pore complex. Journal of Cell Biology, 196(4), 419-434.

Fonseca, T., Lima., F., and Pereira. S. C. (2018). Job polarization, technological change and routinization: Evidence for Portugal. Labour Economics, 51, 317-339.

Goldin C. and Katz, L. (2008). The race between education and technology. Belknap Press for Harvard University Press; 2008.

Goos, M., Manning, A., Salomons, A. (2014). Explaining job polarization: routine-biased technological change and offshoring. American Economic Review, 104(8), 2509-26.

Goos, M. and Manning, A. (2007). Lousy and lovely jobs: the rising polarization of work in Britain. Review of Economics and Statistics, 89(1), 118-133.

Grossman, G. M. and Rossi-Hansberg, E. (2012). Task trade between similar countries. Econometrica, Econometric Society, 80(2), 593-629.

Hainmueller, J., Hiscox, M., Margalit, Y. (2014). Do concerns about labour market competition shape attitudes towards immigration? New evidence. Journal of International Economics, 97(2015), 193-207.

Hardy, W., Keister, R. and Lewandowski, P. (2018). Educational upgrading, structural change and the task composition of jobs in Europe. Economics of Transition, 26(2), 201-231.

Harrigan, J., Reshef, A, and Toubal, F. (2017). Techies, productivity and skill: firm level evidence from France. Online. Available at: http://www.cepii.fr/PDF_PUB/wp/2018/wp2018-21.pdf.

Hausman, J. A. (1978). Specification tests in econometrics. Econometrica, 46, 1251-1271. International Labour Organization, (2018). Online. Available at: https://www.ilo.org/public/english/bureau/stat/isco/isco08/index.htm.

Katz, L. F. and Autor, D. H. (1999). Changes in the Wage Structure and Earnings Inequality, in Orley Ashenfelter and David Card. Handbook of Labour Economics, Vol. 3A. Amsterdam: Elsevier Science, North-Holland, 1463-1555.

Kao, C. (1999). Spurious regression and residual-based tests for cointegration in panel data. Journal of Econometrics, 90, 1-44. 
Leonardi, M. (2010). The effect of product demand on inequality: evidence from the US and the UK. IZA discussion papers, 5011, Institute for the Study of Labour (IZA).

Levin, A. and Chien-Fu, L. (1992). Unit root test in panel data: asymptotic and finite sample properties. Discussion Paper, No 92-93, University of California at San Diego.

Levy, F. and Murnane, R. (2005). The new division of labour, how computers are creating the next job market. Princeton University Press. Book excerpt accessed. Online. Available at: http://www.milkeninstitute.org/publications/review/2004_12/61_82mr24.pdf.

Mazzolari, F. and Ragusa, G. (2007). Spillovers from High-Skill Consumption to LowSkill Labour Markets'. IZA Discussion Papers, 3048, Institute for the Study of Labour (IZA).

Miller, B. and Atkinson, R. D. (2013). Are robots taking our jobs, or making them? Information Technology \& Innovation Foundation. Online: Available at: http://www.itif. org/publications/are-robots-taking-our-jobs-or-making-them.

Ngai, L. R. and Pissarides, C. A. (2007). Structural change in a multisector model of growth. The American Economic Review, 97(1), 429-443.

Oesch, D. and Rodriguez, M. J. (2011). Upgrading or polarization? Occupational change in Britain, Germany, Spain and Switzerland, 1990-2008. Socio-Economic Review, 2011, 9(3).

Pertold-Gebicka, B. (2014). Job market polarization and employment protection in europe. Economics Working Papers.

Pesaran, M. H., Shin, Y. and Smith, R. P. (1999). Pooled mean group estimation of dynamic heterogeneous panels. Journal of the American Statistical Association, 94, 621-634.

Rotman, D. (2013). How technology is destroying jobs. Technology Review, July/August, $28-35$.

Sarkar, S. (2017). Employment polarization and over-education in Germany, Spain, Sweden and UK. Empirica, 44(3), 435-463.

Solow, R. (1956). A contribution to the theory of economic growth. Quarterly Journal of Economics, 70, 65-94.

Spitz-Oener, A. (2006). Technical change, job tasks and rising educational demand: looking outside the wage structure. Journal of Labour Economics, 24(2), 235-270.

Tahlin, M. (2007). Skills and wages in European labour markets: structure and change. In Gallie, D. (ed.) Employment Regimes and the Quality of Work, Oxford, Oxford University Press, 35-76.

Thoenig, M. and Verdier T. (2003). A theory of defensive skill-biased innovation and globalization. American Economic Review, 93(3), 709-728, June.

Tüzemen, D. and Willis, J. (2013). The vanishing middle: job polarization and workers response to the decline in middle-skill jobs. Economic Review, Federal Reserve Bank of Kansas City, 5.

Vivarelli, M. (2014). Innovation, employment and skills in advanced and developing countries: A survey of economic literature. Journal of Economic Issues, 48, 123-154.

Yotam, M. (2011). Costly Jobs: Trade-related Layoffs, Government Compensation, and Voting in U.S. Elections. American Political Science Review, 105, 1. 